Radosław KICIŃSKI, Wojciech JURCZAK, Monika JABŁOŃSKA

Polish Naval Academy (Akademia Marynarki Wojennej)

\title{
TECHNICAL ASPECT CONCERNING VESSELS HALT SAFETY UPON TERRORIST HAZARD
}

\section{Techniczny aspekt zapewnienia bezpieczeństwa postoju okrętów w świetle zagrożeń terrorystycznych}

\begin{abstract}
The article presented and analysed the reliability of water barriers as one of the methods of securing naval technical facilities against the terrorist attacks (motorboats with explosive materials) from the sea. Water tests of FOXX barriers were described as a means of protection against such a threat. The reliability of the barrier was modelled and simulated with the use of Finite Element Method (FEM).
\end{abstract}

Keywords: FEM, safety barriers, water barriers

Streszczenie: $W$ artykule przedstawiono $i$ przeanalizowano wytrzymałość barier pływających jako jednej z metod zabezpieczenia morskich obiektów technicznych przed działaniem terrorystycznym (motorówki z ladunkiem wybuchowym) od strony morza. Opisano testy pływajacej bariery FOXX jako środka ochrony przed takim zagrożeniem. Zamodelowano i przeprowadzono symulację wytrzymałości bariery wykorzystujac metode elementów skończonych.

Słowa kluczowe: metoda elementów skończonych, bariery zabezpieczające, bariery wodne 


\section{Introduction}

Nowadays, asymmetric conflicts are very intensive over the whole world. The asymmetric conflict means diversity in the structure of the organization as well as the way of thinking. In this type of conflicts, it is pursued so that neither side decides to use its military advantages, even when it is possible for tactical or technical reasons [6]. A good example of asymmetric conflict may be an attack on USS Cole, which has been attacked by suicide bombers during fuel refilling in the harbour. The Al - Qaida members hit the warship with a small motorboat filled with explosives. The explosion killed 17 and injured 39 soldiers [2].

Using the large calibre guns against motorboat seems to be unjustified tactically or economically, but losses in a ship's hull lead to other conclusions (fig. 1).

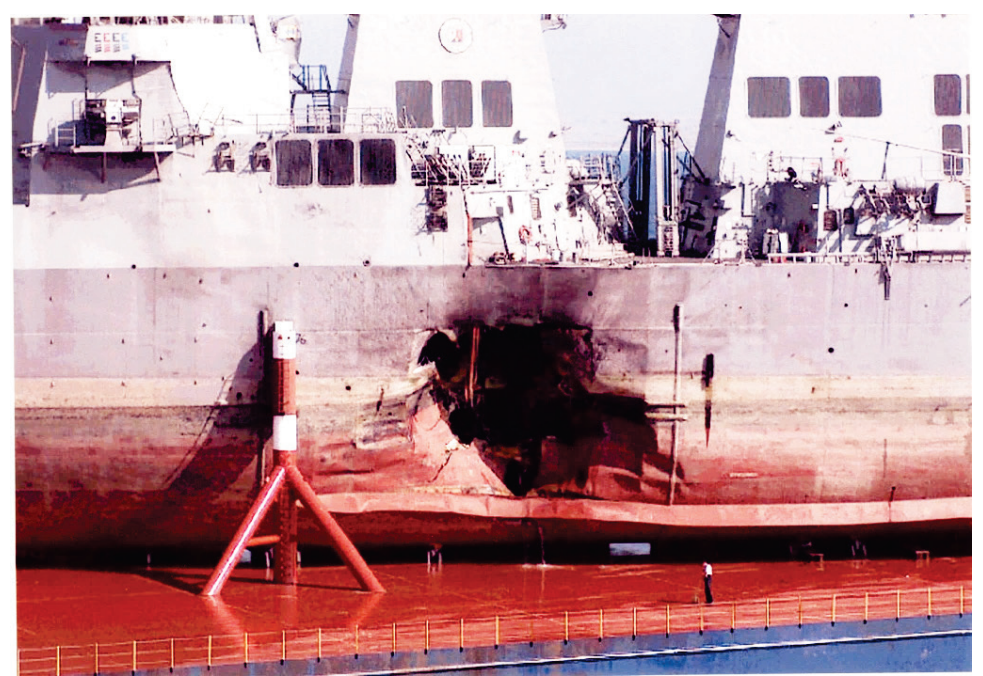

Fig. 1. USS Cole after suicide bombing

(Source: https://www.fbi.gov/history/famous-cases/uss-cole-bombing

The increasing acts of piracy and the diversity of asymmetric threats require remedies. For warships, the security team may be created that will patrol the whole ship, while for cargo ships in case of emergency the sprinkles using hot or high-pressure water may be used. The given example also showed that in the port, the terroristic threat also exists.

Cargo ships are also exposed to dangerous activities not only during transit but also when they are in a port. For the protection of the land side, the wall made of containers may be used. The wall can be easy dismantled after unmooring the unit. It is much more difficult to make a defence from the sea. One of the solutions might be mesh floating protective barriers. 
This kind of barriers may be used for port protection as well as to protect various types of strategic facilities such as gas terminals, power plants, dams and bridges.

The manufacturer ensures that the barriers are made with a high yielding stainless steel. The construction is made to absorb a large portion of impact energy. It is also easy to maintain in hard marine condition; it does not limit the observation field; it is also resistant to UV radiation, fire, detonation and insensitive to bullets. The manufacturer also ensures that the motorboats are unable to slip neither under or over the barrier $[3,7]$.

\section{Tests of the FOXX floating barrier}

On 02.11 - 05.11.2010, on the waters of the Zakrzówek Lagoon in Krakow, realistic tests in the 1:1 scale of the floating mesh water barrier FOXX produced by Geobrugg AG were carried out. The tested FOXX barrier consists of modules made from MAXX steel net. The modules were connected in such a way to compensate water movements and changes in its level. The net forming the floating water barrier is made of a weave of two stainless wires with a diameter of $4 \mathrm{~mm}$. The barrier was created from a basic 50 meters long and 2.4 meters high section. The net is fixed on 4-meter floats. The distance between floats is 3.5 meters. In the upper part, the barrier is equipped with additional steel ropes, which reduce the probability of a fast speedboat getting over the barrier (fig. 2) [7].

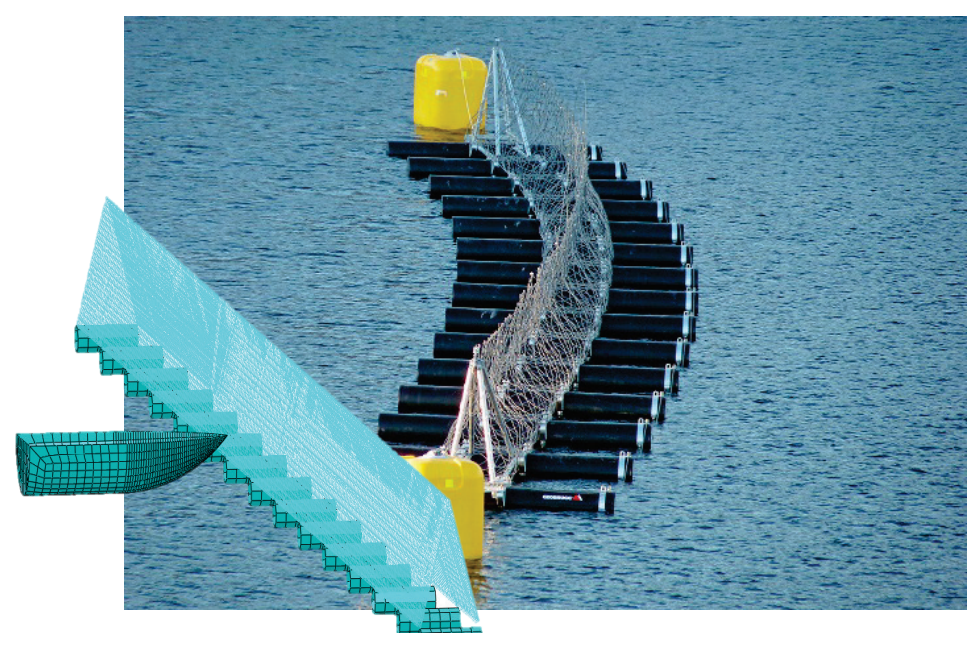

Fig. 2. FOXX floating barrier and its FEM model (Source:http://www.navyrecognition.com/ index.php/news/naval-exhibitions/dimdex-2014/1621-swiss-company-geobruggag-will-present-its-foxx-floating-boat-barrier-at-dimdex-2014.html) 
The paper [7] describes experiments using a "Calypso" motorboat. During the tests, a unit with a weight of $2268 \mathrm{~kg}$ was used.

The following tests were carried out:

- test \# 1 - static test of the "Calypso" type boat (constant boat pressure);

- test \# 2 - front impact on the Calypso boat barrier - the unit speed at the moment of contact with the barrier $10.9 \mathrm{~km} / \mathrm{h}-3.02 \mathrm{~m} / \mathrm{s}$;

- test \# 3 - front impact on the Calypso boat barrier - the unit speed at the moment of contact with the barrier $29.9 \mathrm{~km} / \mathrm{h}-8.3 \mathrm{~m} / \mathrm{s}$;

- test \# 4-a front impact on the "Calypso" boat barrier - the unit speed at the moment of contact with the barrier of $45.4 \mathrm{~km} / \mathrm{h}-12.6 \mathrm{~m} / \mathrm{s}$;

- test \# 5 - front impact on the "RHIB" type boat barrier - the unit speed at the time of contact with barrier $48.0 \mathrm{~km} / \mathrm{h}-13.3 \mathrm{~m} / \mathrm{s}$;

- test \# 6 - front impact on the Calypso boat barrier - the unit speed at the time of contact with the barrier $56.1 \mathrm{~km} / \mathrm{h}-15,58 \mathrm{~m} / \mathrm{s}$.

After analyzing the results, the following conclusions were obtained [7]:

- boat hit at a speed above 20 knots in the float supporting the net causes damage to the hull that could result in the sinking of the unit. The impact force is so large that the boat crew will lose the ability to operate effectively for up to several dozen seconds;

- after each hit of a fast boat, the barrier deformed, however, the size of this deformation was not greater than 4-6\% of the length of the base section (2 to 3 meters). The return to the state of the original shape did not last longer than 5 to 10 seconds;

- during the last attempt, the Calypso boat struck with a kinetic energy of $150 \mathrm{~kJ}$. No significant damage was observed in the barrier; it can be concluded that the barrier is able to effectively stop a boat with much more kinetic energy (larger and moving at higher speed);

- the barrier has a good energy transfer ratio because the construction of the FOXX barrier is characterized by flexible connections. At a distance of 25 meters, the level of kinetic energy was about 12 times smaller than at the point of impact. 


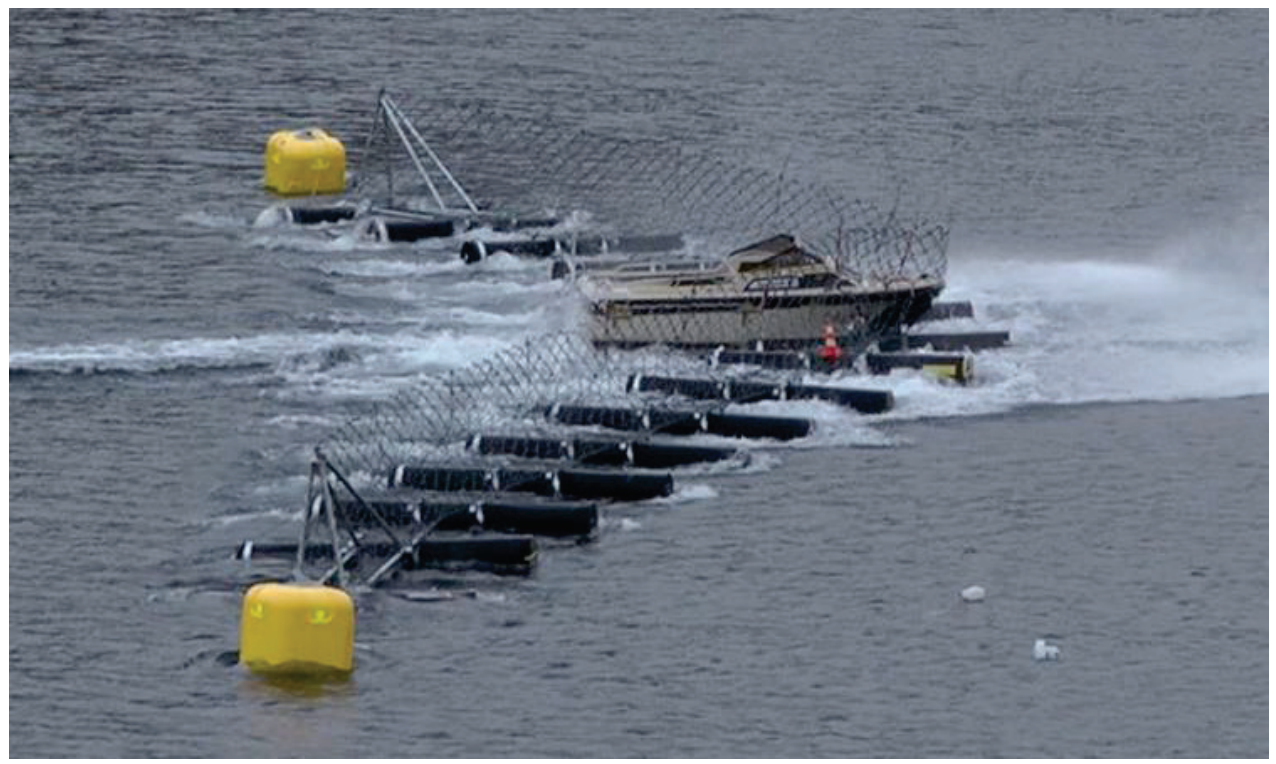

Fig. 3. FOXX barrier during test (Source: http://www.dubib.com/news/2747_foxx-floating-port-security-barrierprotects-sensitive-infrastructure-from-waterside-attacks\#.W21l_dUzaUn)

\section{Modelling barriers with the use of FEM}

The tests did not show that the boat got through the barrier. Due to the labour intensity and the price of large-scale tests, it is worth considering the numerical simulation of maximum strength and maximum floating barrier capacities. The results of macro-scale tests enable the creation of simulations allowing for a fairly reliable examination of barriers for larger, faster and heavier units.

Mesh model was made using shell and beam elements. The convolution of two wires to one MES node has been simplified. Floats were modelled as shell elements, and their mass was selected in such a way as to simulate the resistance of water by the inertia of floats. The whole model was subjected to the analysis of natural vibrations, which did not show any discontinuities of the model (fig. 4). 


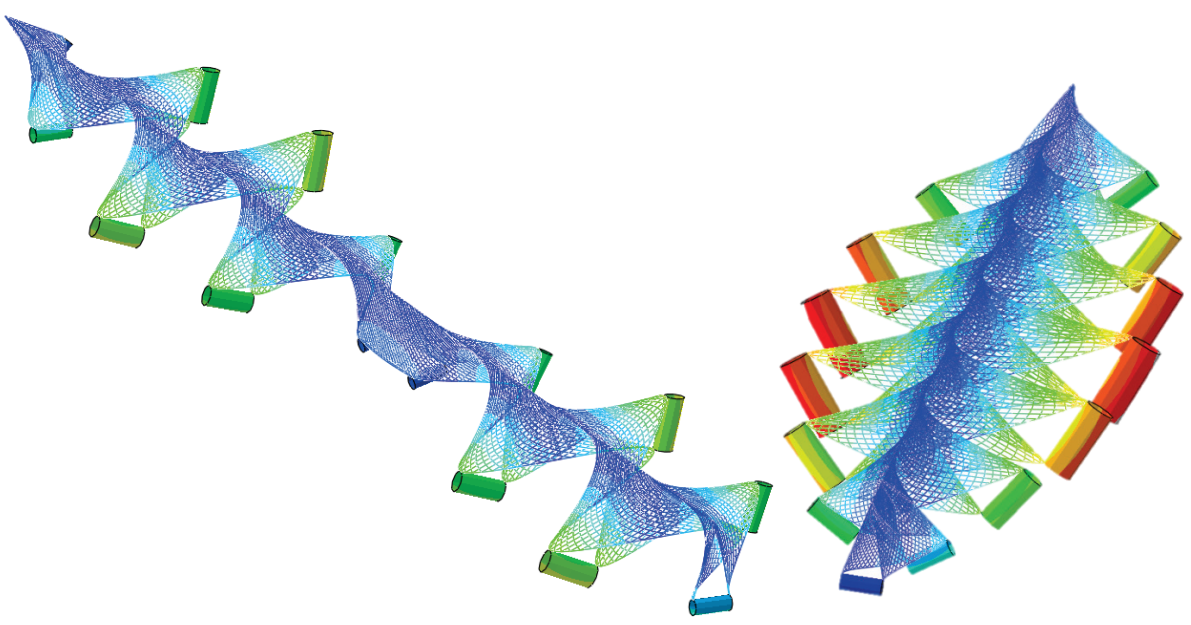

Fig. 4. Analysis of natural vibration

The motorboat was modelled as a rigid body with dimensions $4 \times 2 \times 1 \mathrm{~m}$ and a mass of $2185 \mathrm{~kg}$. The boat model consisted of 4,397 linear shell elements (S4R).

The manufacturer does not define the material from which the barrier was made, however, considering that it is high-strength stainless steel, it was assumed to be AISI 304 steel. In fast-changing processes, such material can be described using the Johnson-Cook polynomial in the form [4]:

$$
\sigma=\left(A+B \varepsilon^{n}\right)\left(1+C \ln \left(\frac{\dot{\varepsilon}}{\dot{\varepsilon}_{0}}\right)\right)\left(1-\frac{T-T_{0}}{T_{m}-T_{0}}\right)^{m}
$$

Where:

$\sigma$ - stresses in the material; $A$ - yield stress; $B$ - strengthening parameter; $\varepsilon-$ reduced plastic deformation; $n$-exponent of the strengthening; $C$-material sensitivity coefficient for deformation speed; $\dot{\varepsilon}$ - reduced speed of plastic deformation; $\dot{\varepsilon}_{0}$ - deformation speed threshold; $T$ - temperature at which the material will work; $T_{0}$-ambient temperature; $T_{m}$ - melting point; $m$-exponent of the softening under the influence of temperature.

The material parameters which were adopted are shown in table 1 . 
Table 1

Material properties of AISI 304 steel [5]

\begin{tabular}{||l|l|l||}
\hline \multicolumn{1}{|c|}{ Parameter } & \multicolumn{1}{c|}{ Unit } & Value \\
\hline$E-$ Young modulus & $\mathrm{GPa}$ & 207,8 \\
\hline$v-$ Poisson ratio, & - & 0,3 \\
\hline$\rho-$ density & $\mathrm{kg} / \mathrm{m} 3$ & 1000 \\
\hline$A-$ yield stress; & $\mathrm{MPa}$ & 280 \\
\hline$B-$ strengthening parameter; & $\mathrm{MPa}$ & 802,5 \\
\hline$\varepsilon-$ reduced plastic deformation; & - & 0,622 \\
\hline$n-$ exponent of the strengthening; & - & 0,0799 \\
\hline$\dot{\varepsilon}_{\mathbf{0}}-$ deformation speed threshold; & $1 / \mathrm{s}$ & 1,0 \\
\hline$R_{m}-$ ultimate strength & $\mathrm{MPa}$ & 540 \\
\hline
\end{tabular}

\section{Simulation results}

The article presents the simulation of the fast-changing process, which is a collision of a motorboat with a fixed obstacle (FOXX barrier). A series of simulations were carried out in relation to experiments. Based on the conclusions from the paper [7], the mass of floats was chosen so that the deformations of the grid sections were not more than 4 meters after the impact. The reference to the energy parameter, which is the dissipation of energy in the barrier was made. The results of the simulation are shown below. The simulation time was 4 seconds. The tests were carried out with initial velocity equal to $3.02 \mathrm{~m} / \mathrm{s}, 8.3 \mathrm{~m} / \mathrm{s}, 12.6 \mathrm{~m} / \mathrm{s}$ and $15.5 \mathrm{~m} / \mathrm{s}$. The results are presented in the drawings and diagrams. 

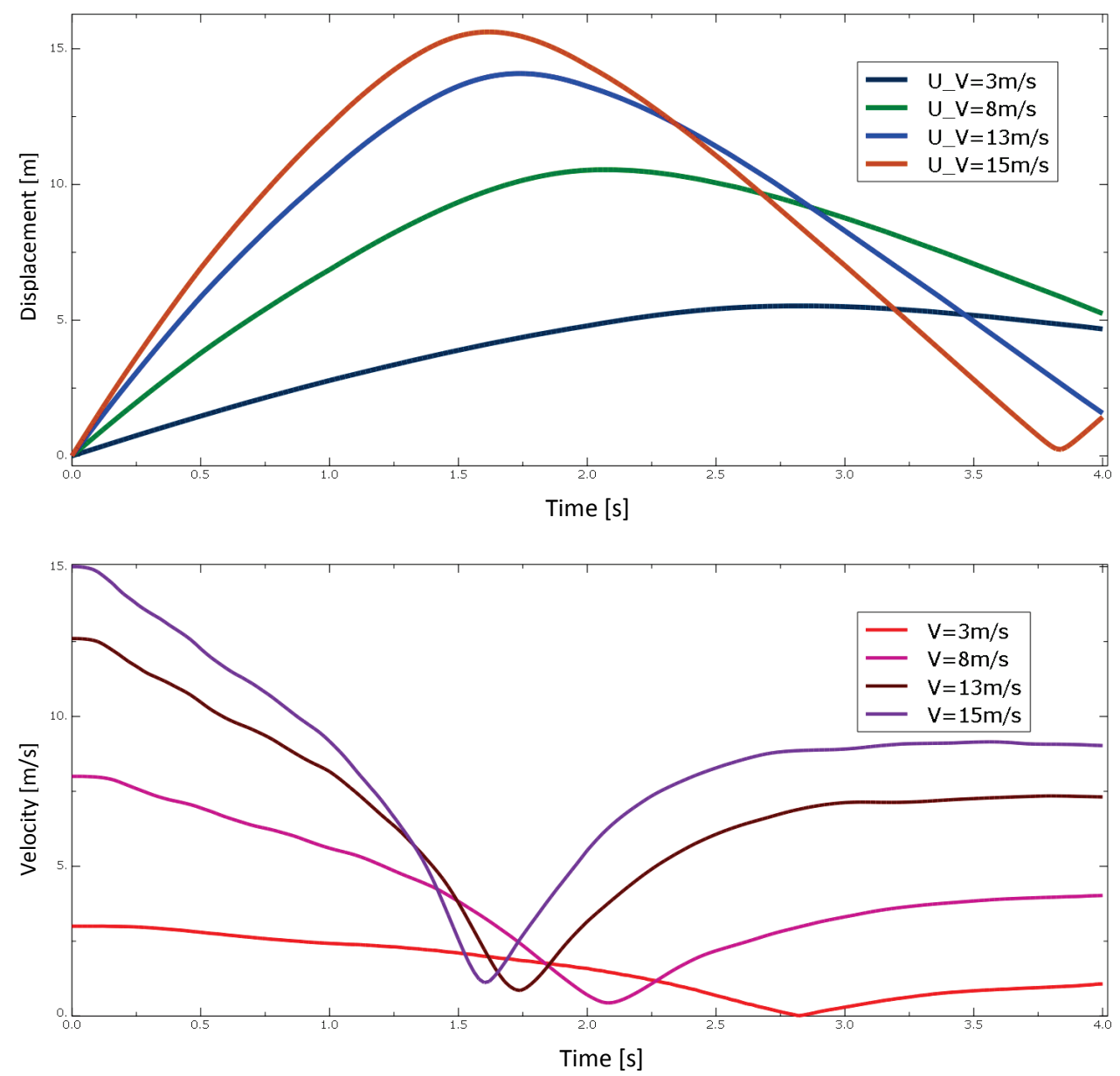

Fig. 5. Graphs showing the displacement and velocity of the boat 


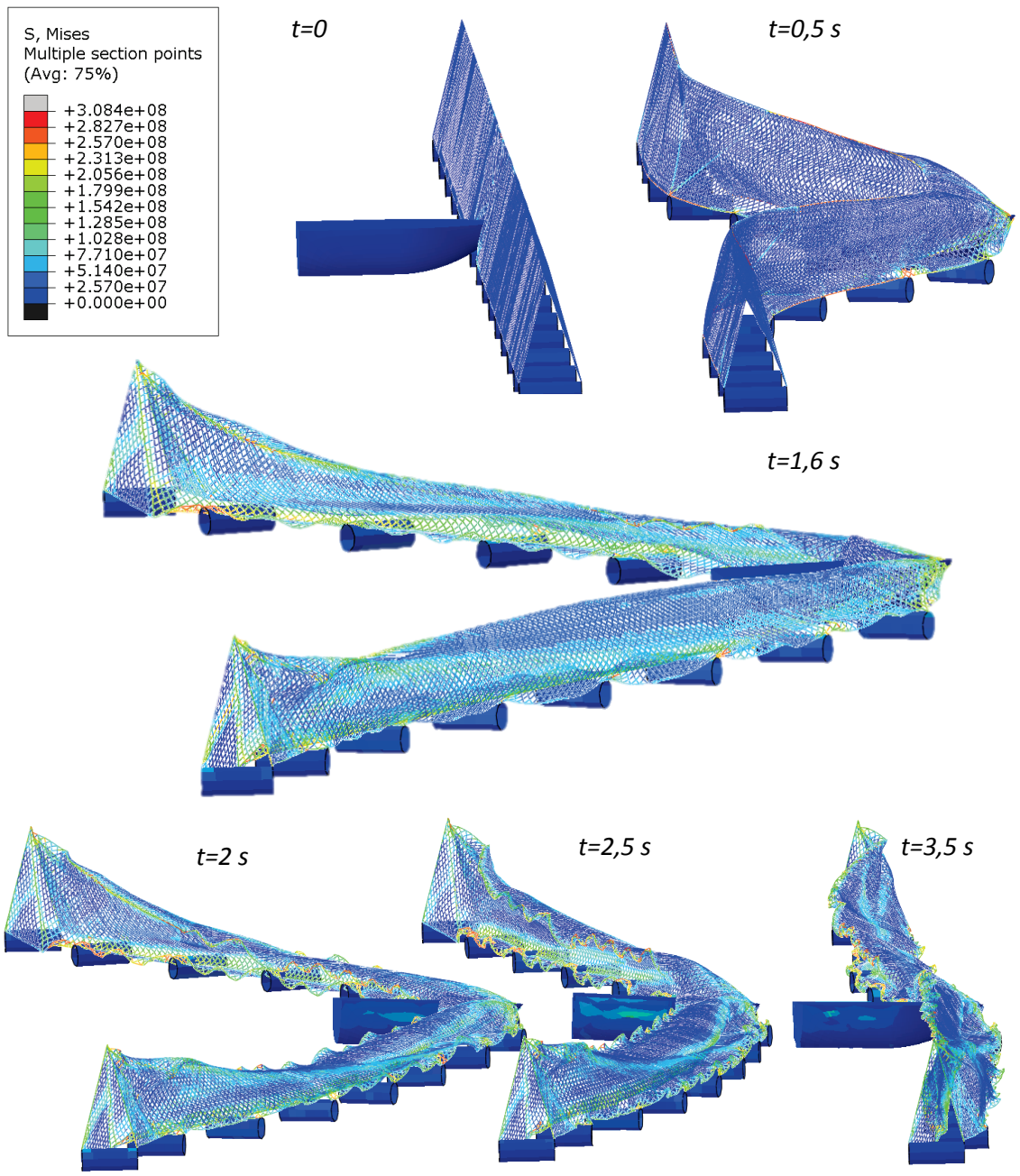

Fig. 6. Distribution of stresses in time steps for a collision at velocity $\mathrm{V}=15.58 \mathrm{~m} / \mathrm{s}$

The paper presents the speed dissipation and the maximum displacement of the boat's stem. The results indicate compatibility with the experiment because the net, even after the boat hits the highest speed, returns to its initial position. Stresses in the barrier also lead to these conclusions. According to the results of the calculations, the maximum stresses are $308.4 \mathrm{MPa}$, which slightly exceeds the yield point of the modelled material (fig. 7). The concentration of maximum stress is not at the point of impact, which is the result of simplifications and imperfections of the model. 


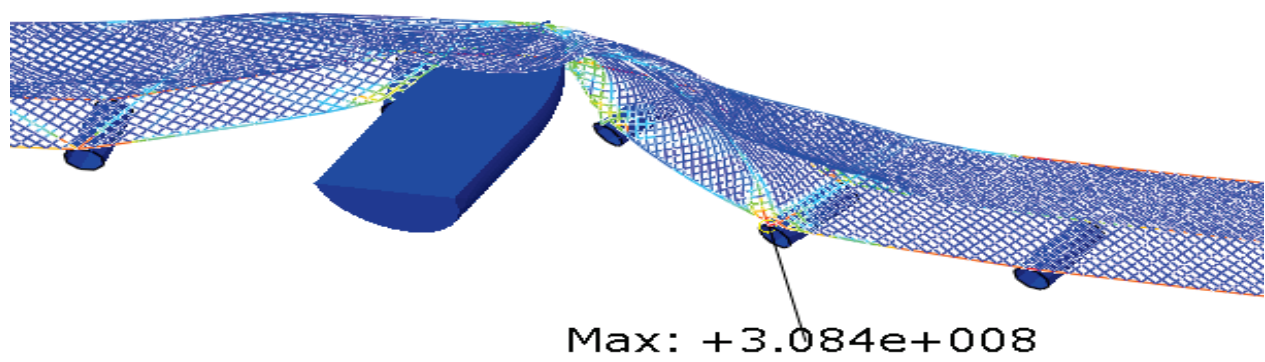

Fig. 7. The place where the maximum stress occurred (308.4 MPa)

\section{Summary}

The article presents the FOXX floating barriers as a means of protection against the dangers of the sea when the ship remains in port. The tests carried out at the Zakrzówek Lagoon in Krakow were described, and the conclusions from the conducted experiments were quoted. Next, the FEM model of the barrier was created, and simulations were performed based on experiments. The results are presented in the form of graphs and drawings. Based on the results, the following conclusions were made:

- the appropriate weight of the swimmers is able to simulate water resistance during the impact. Based on multiple simulations, the mass of swimmers was chosen in such a way to reflect the behaviour of the barrier. The weight of the floats in the simulation was $45 \mathrm{~kg}$;

- during the collision at maximum speed, the stresses in the net reached the yield point of the modelled material but did not exceed the limit of strength at the impact location. The plasticity limit was exceeded at the node in which the simplification of attaching the floating net was modelled. In the real barrier, this place is reinforced, which allows it to be excluded as a place of concentration of stresses;

- the velocity dissipation in the barrier depends on the velocity of the impact. The collision at a higher speed causes the boat to decelerate more quickly. The maximum displacement of the boat is $15 \mathrm{~m}$, after which the boat begins to move in the opposite direction. The simulation results show that the barrier absorbs an average of $25 \%$ of the kinetic energy of the collision.

Analyzing the result of the experiment, it was found that there is a possibility for a large speedboat to get through the barrier. The model allows to check the 
possibility of passing over the barrier of any unit; however, due to the multitude of different structures, they are not presented in this article.

The presented article includes the results of research conducted within the framework of the project 'AUSTENKA' code M-1-1-1-021/20018 funded by the Polish Ministry of Defence (MON).

\section{References}

1. Abaqus 6.10, Theory Manual, Simulia, Dassault Systems, 2010.

2. Casualties: U.S. Navy and Marine Corps Personnel Killed and Wounded in Wars, Conflicts, Terrorist Acts, and Other Hostile Incidents. Naval History \& Heritage Command. Retrieved 15 July 2012.

3. https://www.naval-technology.com/contractors/fenders/geobrugg/

4. Johnson G.R., Cook W.H.: A Constitutive model and data for metal subjected to large strains, high strain rates and high temperatures, Proceedings of the 7 th International Symposium on Ballistics, 2009.

5. Krasauskas P., Kilikevičius S., Česnavičius R., Pačenga D.: Experimental analysis and numerical simulation of the stainless AISI 304 steel friction drilling proces. MECHANIKA, vol. 20 (6), 2014.

6. Kubiak K.: Broń nieśmiercionośna we współczesnych konfliktach zbrojnych. Zeszyty Naukowe AON, No. 1(70), Warszawa 2008.

7. Szubrycht T., Kowalski S.: Teoretyczne i praktyczne aspekty przeprowadzonych testów pływających siatkowych barier ochronnych. Logistyka, No. 5, 2011. 


\section{TECHNICZNY ASPEKT ZAPEWNIENIA BEZPIECZEŃSTWA POSTOJU OKRĘTÓW W ŚWIETLE ZAGROŻEŃ TERRORYSTYCZNYCH}

\section{Wstęp}

Na świecie coraz częściej spotyka się konflikty asymetryczne. Termin ten oznacza między innymi zróżnicowanie w sposobie organizacji, myślenia i taktyki prowadzenia konfliktów zbrojnych. W konflikcie asymetrycznym dąży się do takiego rozegrania, aby żadna ze stron nie zdecydowała się na wykorzystanie swojej przewagi nawet, gdy jest to możliwe ze względów taktycznych czy technicznych [6]. Dobrym przykładem potyczki asymetrycznej jest atak na niszczyciel USS Cole, który w 2000 r. został zaatakowany przez zamachowców samobójców podczas tankowania w porcie. Członkowie Al-Kaidy uderzyli w burtę okrętu niewielką motorówką wypełnioną materiałami wybuchowymi zabijając 17 oraz raniąc 39 marynarzy [2].

Analizując ten fakt, wnioskować można, że nie było ani czasu ani możliwości wykorzystania uzbrojenia okrętowego przeciw zbliżającej się z dużą prędkością motorówce. Uderzenie tej małej łodzi motorowej, spowodowało duże straty w ludziach i okrętowym sprzęcie (rys.1). Niebezpieczeństwo ataku dotyczy także infrastruktury portowo-stoczniowej, dlatego poszukuje się różnych metod zabezpieczenia dla postoju okrętów w porcie. 


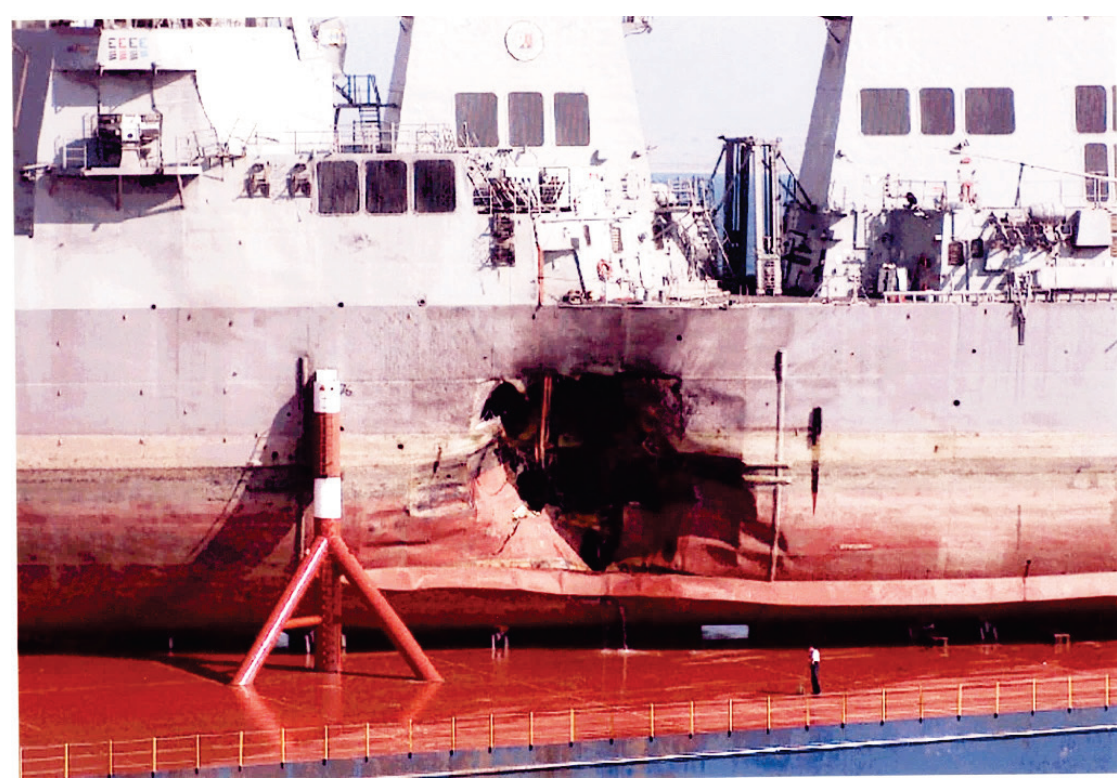

Rys. 1. USS Cole po zamachu samobójczym (Źródło:

https://www.fbi.gov/history/famous-cases/uss-cole-bombing )

Zwiększające się akty piractwa i terroryzmu, mnogość oraz różnorodność zagrożeń asymetrycznych wymagają środków zaradczych. Dla okrętów wojennych można stworzyć zespół ochrony i ustanowić patrole w razie zagrożenia, natomiast dla statków w przypadku zagrożenia można zastosować odpowiednie spryskiwacze pozwalające rozprowadzać wodę pod dużym ciśnieniem czy też wysokiej temperaturze wokół statku. W czasie postoju w porcie jednostki pływającej (okręt, statek) zagrożenie oraz skuteczność działania terrorystycznego jest znacznie większe niż podczas pływania (tranzytu).

Jednostki pływające narażone są na niebezpieczne działania nie tylko podczas tranzytu, ale również podczas postoju w porcie. Zabezpieczenie od strony lądu może być wykonywane m.in. poprzez wykorzystanie muru zbudowanego z kontenerów, który można łatwo rozmontować po odcumowaniu jednostki. Trudniej jest wykonać obronę pasywną od strony morza. Jednym z rozwiązań tego problemu mogą być pływające siatkowe bariery ochronne.

Bariery te mogą być wykorzystywane w portach, jak również do ochrony różnego rodzaju obiektów strategicznych, takich jak terminale gazowe, elektrownie, tamy czy mosty.

Producent zapewnia, że są one wykonane ze stali nierdzewnej cechującej się dużą wytrzymałością. Konstrukcja zapewnia dużą absorbcję energii oraz wytrzymałość i łatwość utrzymania w trudnych warunkach morskich. Ze względu 
na swoją konstrukcję bariera nie ogranicza pola obserwacji jest odporna na promieniowanie UV, ogień, detonacje oraz ostrzelanie z broni palnej. Producent zapewnia także o braku możliwości przedostania się łodzi motorowych zarówno pod, jak i nad barierą $[3,7]$.

\section{Testy pływającej bariery wodnej FOXX}

W 2010 r. na wodach Zalewu Zakrzówek w Krakowie przeprowadzono rzeczywiste testy $\mathrm{w}$ skali 1:1 pływającej siatkowej wodnej bariery FOXX wyprodukowanej przez firmę Geobrugg AG. Testowana bariera składa się z modułów, których głównym elementem jest siatka stalowa MAXX, połączonych tak, aby kompensować ruchy wody oraz zmiany jej poziomu. Siatka tworząca pływającą barierę wodną wykonana jest ze splotu dwóch nierdzewnych drutów o średnicy $4 \mathrm{~mm}$. Bariera tworzona jest $\mathrm{z}$ dowolnej liczby sekcji podstawowych o długości $50 \mathrm{~m}$ i wysokości 2,4 m. Siatka tworząca każdą z sekcji podstawowych mocowana jest na 4-metrowych pływakach. Odstępy między kolejnymi pływakami wynoszą $3,5 \mathrm{~m}$. W górnej części bariera wyposażona została w dodatkowe liny, co zmniejsza prawdopodobieństwo przedostania się szybkiej łodzi motorowej ponad nią (rys. 2) [7].

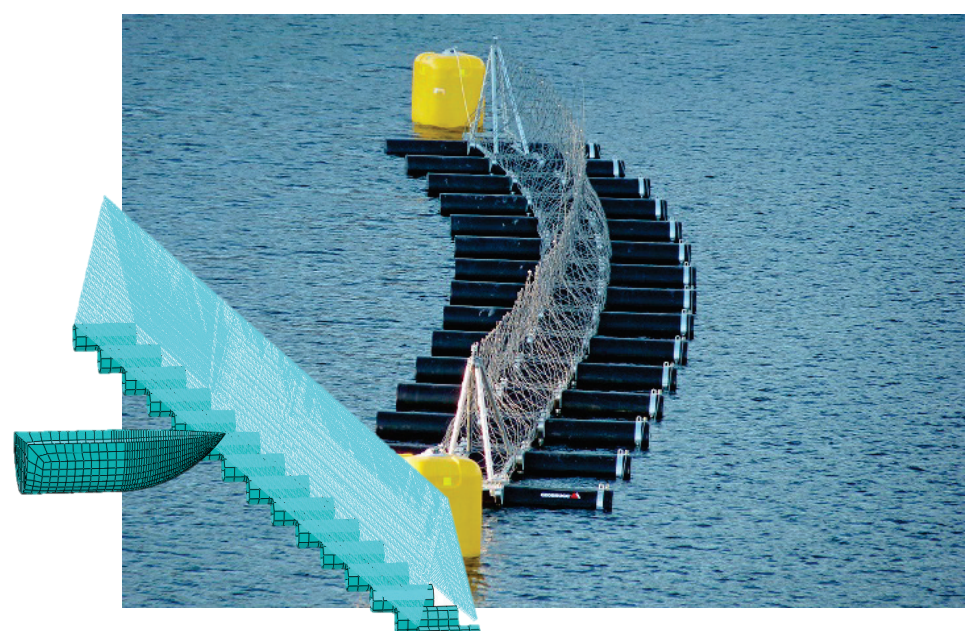

Rys. 2. Bariera pływająca FOXX oraz jej model wraz z siatką MES

(Źródło:http://www.navyrecognition.com/index.php/news/navalexhibitions/dimdex-2014/1621-swiss-company-geobrugg-ag-will-present-itsfoxx-floating-boat-barrier-at-dimdex-2014.html) 
W pozycji [7] przeglądu literatury opisano przebieg eksperymentów z wykorzystaniem łodzi motorowej typu „Calypso”. W trakcie testów wykorzystano jednostkę o masie całkowitej do $2268 \mathrm{~kg}$.

Przeprowadzono następujące testy:

- test \#1 - test statyczny łodzi typu „Calypso” (stały napór czołowy łodzi);

- test \#2 - czołowe uderzenie w barierę łodzi typu „Calypso” - prędkość jednostki w momencie kontaktu z bariera $10,9 \mathrm{~km} / \mathrm{h}-3,02 \mathrm{~m} / \mathrm{s}$;

- test \#3 - czołowe uderzenie w barierę łodzi typu „Calypso" - prędkość jednostki w momencie kontaktu z barierą $29,9 \mathrm{~km} / \mathrm{h}-8,3 \mathrm{~m} / \mathrm{s}$;

- test \#4 - czołowe uderzenie w barierę łodzi typu „Calypso” - prędkość jednostki w momencie kontaktu z barierą $45,4 \mathrm{~km} / \mathrm{h}-12,6 \mathrm{~m} / \mathrm{s}$;

- test \#5 - czołowe uderzenie w barierę łodzi typu „RHIB” - prędkość jednostki w momencie kontaktu z barierą $48,0 \mathrm{~km} / \mathrm{h}-13,3 \mathrm{~m} / \mathrm{s}$;

- test \#6 - czołowe uderzenie w barierę łodzi typu "Calypso" - prędkość jednostki w momencie kontaktu z barierą $56,1 \mathrm{~km} / \mathrm{h}-15,58 \mathrm{~m} / \mathrm{s}$.

Po przeanalizowaniu wyników testów otrzymano poniższe wnioski [7]:

- uderzenie łodzi przy prędkości powyżej 20 węzłów w pływak podtrzymujący siatkę powoduje uszkodzenie kadłuba mogące skutkować zatonięciem jednostki. Siła uderzenia jest tak duża, iż załoga łodzi bądź utraci możliwość skutecznego działania na okres od kilkunastu do kilkudziesięciu sekund;

- po każdym uderzeniu szybkiej łodzi bariera odkształcała się, jednak wielkość tego odkształcenia nie była większa niż 4-6\% długości sekcji podstawowej ( 2 do 3 metrów). Powrót do stanu kształtu pierwotnego nie trwał dłużej niż 5 do 10 sekund;

- podczas ostatniej próby łódź Calypso uderzała $\mathrm{z}$ energią kinetyczną wynoszącą $150 \mathrm{~kJ}$. Nie zaobserwowano istotnych zniszczeń w barierze, a tym samym można wnioskować, że bariera jest w stanie skutecznie powstrzymać łódź o znacznie większej energii kinetycznej (większej i poruszającej się z większą prędkościa);

- cechuje ją bardzo dobry współczynnik przenoszenia energii, ponieważ budowę bariery FOXX charakteryzują elastyczne połączenia. W odległości $25 \mathrm{~m}$ poziom energii kinetycznej był około 12 razy mniejszy, niż w punkcie uderzenia. 


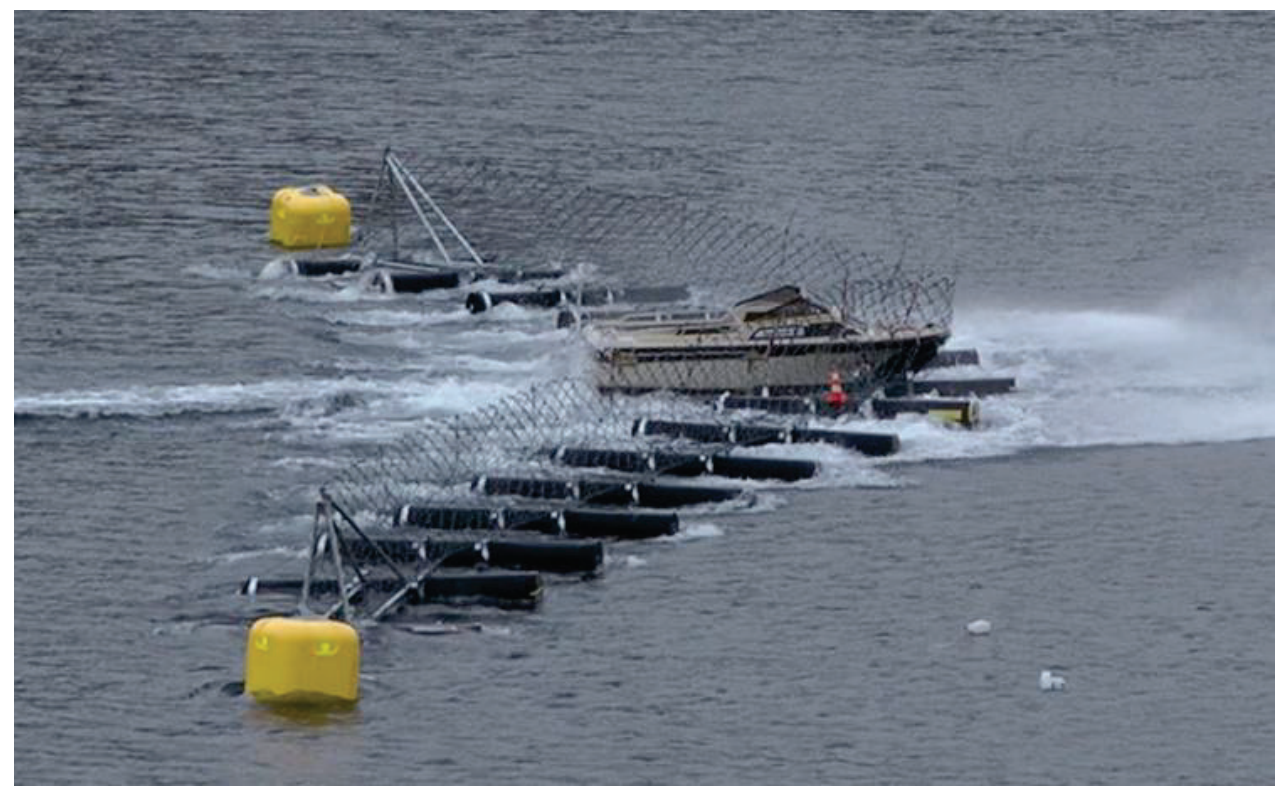

Rys. 3. Bariera FOXX podczas testów (Źródło: http://www.dubib.com/news/2747_foxxfloating-port-security-barrier-protects-sensitive-infrastructure-from-watersideattacks\#.W21l_dUzaUn)

\section{Modelowanie barier siatkowych $\mathrm{z}$ wykorzystaniem MES}

Testy nie wykazały, aby którakolwiek z łodzi przedostała się przez barierę. Ze względu na pracochłonność oraz cenę testów w dużej skali warto zastanowić się nad symulacją numeryczną maksymalnej wytrzymałości oraz możliwości barier pływających. Wyniki testów w skali makro umożliwiają stworzenie symulacji pozwalającej na dość wiarygodne sprawdzenie barier dla większych, szybszych i cięższych jednostek.

Model siatki wykonano wykorzystując elementy belkowe oraz powłokowe. Uproszczono splot dwóch drutów do jednego węzła MES. Pływaki zamodelowano jako elementy powłokowe oraz dobrano ich masę w taki sposób, aby odpowiednio zasymulować opór wody poprzez inercję pływaków. Całość modelu poddano analizie drgań własnych, która nie wykazała nieciagłości modelu (rys. 4). 


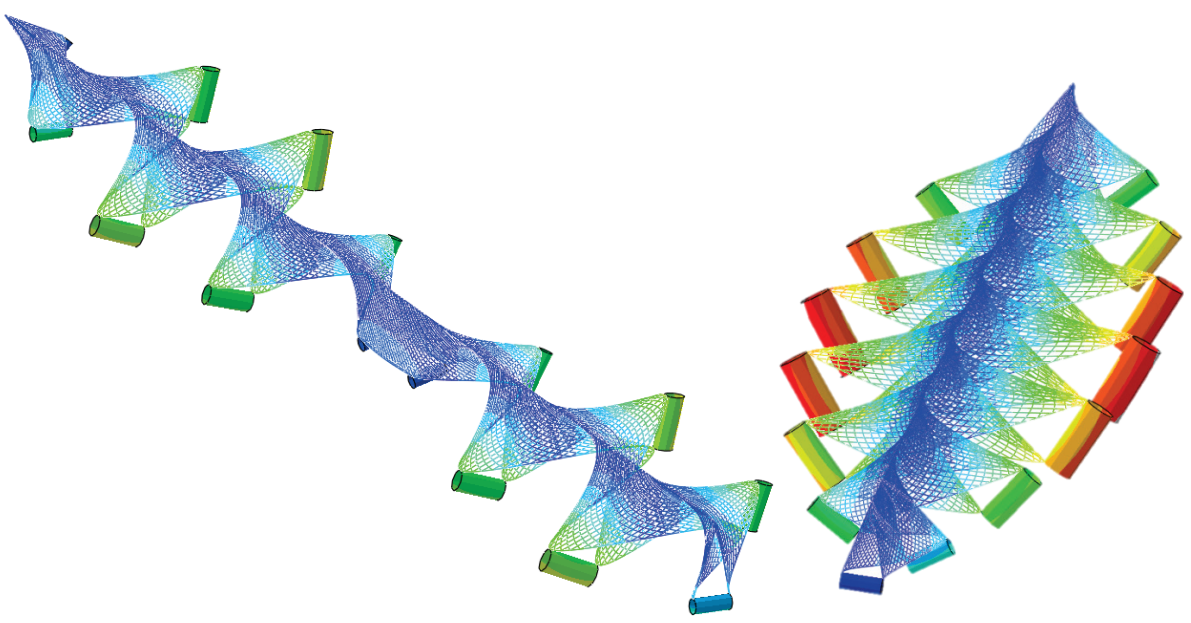

Rys. 4. Analiza drgań własnych bariery

Łódź motorową zamodelowano jako element powłokowy - ciało doskonale sztywne o wymiarach 4x2x1 m oraz masie $2185 \mathrm{~kg}$. Model łodzi składał się z 4397 powłokowych elementów liniowych S4R.

Producent nie definiuje materiału z jakiego została wykonana bariera, jednakże biorąc pod uwagę, że jest to wysoko wytrzymała stal nierdzewna założono, że jest to stal AISI 304. W procesach szybkozmiennych materiał taki można opisać za pomocą wielomianu Johnsona-Cooka w postaci [4]:

$$
\sigma=\left(A+B \varepsilon^{n}\right)\left(1+C \ln \left(\frac{\dot{\varepsilon}}{\dot{\varepsilon}_{0}}\right)\right)\left(1-\frac{T-T_{0}}{T_{m}-T_{0}}\right)^{m}
$$

\section{Gdzie:}

$\sigma$ - naprężenia w materiale; $A$ - granica plastyczności materiału; $B$ - parametr umocnienia; $\varepsilon$-zredukowane odkształcenie plastyczne; $n$-wykładnik umocnienia; $C$ - współczynnik wrażliwości materiału na prędkość odkształcenia; $\dot{\varepsilon}-$ zredukowana prędkość odkształcenia plastycznego; $\dot{\varepsilon}_{0}-$ próg prędkości odkształcenia; $T$-temperatura, w jakiej będzie pracował materiał; $T_{0}$-temperatura otoczenia; $T_{m}$ - temperatura topnienia; $m$ - wykładnik zmiękczanie pod wpływem temperatury.

Pomijając właściwości temperaturowe dla stali AISI 304 przyjęto na podstawie literatury odpowiednie parametry materiałowe, które przedstawiono w tabeli 1. 


\section{Tabela 1}

Wlaściwości materiałowe stali AISI 304 Błąd! Nie można odnaleźć źródła odwołania.

\begin{tabular}{|l|l|l|}
\hline \multicolumn{1}{|c|}{ Parametr } & \multicolumn{1}{c|}{ Jednostka } & \multicolumn{1}{c|}{ Wartość } \\
\hline$E$ - moduł Younga & $\mathrm{GPa}$ & 207,8 \\
\hline$v$ - współczynnik Poissona, & - & 0,3 \\
\hline$\rho-$ gęstość & $\mathrm{kg} / \mathrm{m}^{3}$ & 1000 \\
\hline$A-$ granica plastyczności materiału; & $\mathrm{MPa}$ & 280 \\
\hline$B$ - parametr umocnienia; & $\mathrm{MPa}$ & 802,5 \\
\hline$n-$ wykładnik umocnienia; & - & 0,622 \\
\hline $\begin{array}{l}C-\text { współczynnik wrażliwości materiału na prędkość } \\
\text { odkształcenia; }\end{array}$ & - & 0,0799 \\
\hline$\dot{\varepsilon}_{\mathbf{0}}-$ próg prędkości odkształcenia; & $1 / \mathrm{s}$ & 1,0 \\
\hline$R_{m}-$ granica wytrzymałości & $\mathrm{MPa}$ & 540 \\
\hline \hline
\end{tabular}

\section{Wyniki symulacji}

W pracy przedstawiono symulacje procesu szybkozmiennego - zderzenia łodzi motorowej ze stałą przeszkoda, jaką jest bariera siatkowa FOXX. Przeprowadzono wiele symulacji w odniesieniu do eksperymentów. Opierając się na wnioskach z pracy [7] dobrano masę pływaków w taki sposób, aby odkształcenia sekcji siatki nie wynosiły więcej niż $4 \mathrm{~m}$ po uderzeniu, a także odniesiono się do parametru energetycznego jakim jest rozproszenie energii w barierze. Wyniki symulacji przedstawiono poniżej. Czas symulacji wynosił $4 \mathrm{~s}$. Przeprowadzono testy z prędkością początkową równą: $3,02 \mathrm{~m} / \mathrm{s} ; 8,3 \mathrm{~m} / \mathrm{s}, 12,6 \mathrm{~m} / \mathrm{s}$ oraz $15,58 \mathrm{~m} / \mathrm{s}$. Wyniki przedstawiono na rysunkach oraz wykresach. 

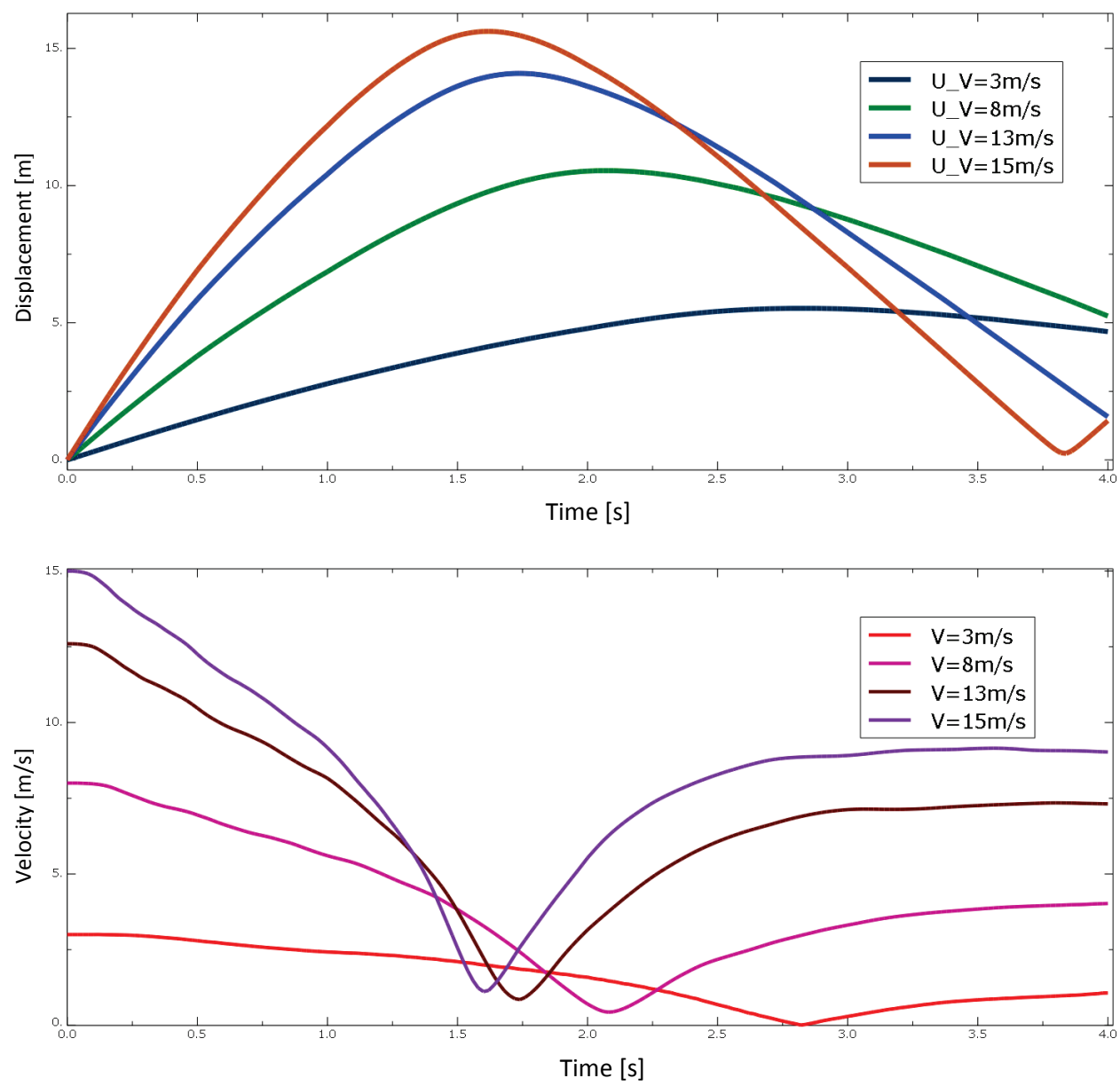

Rys. 5. Wykresy przedstawiające przemieszczenie oraz prędkość łodzi 


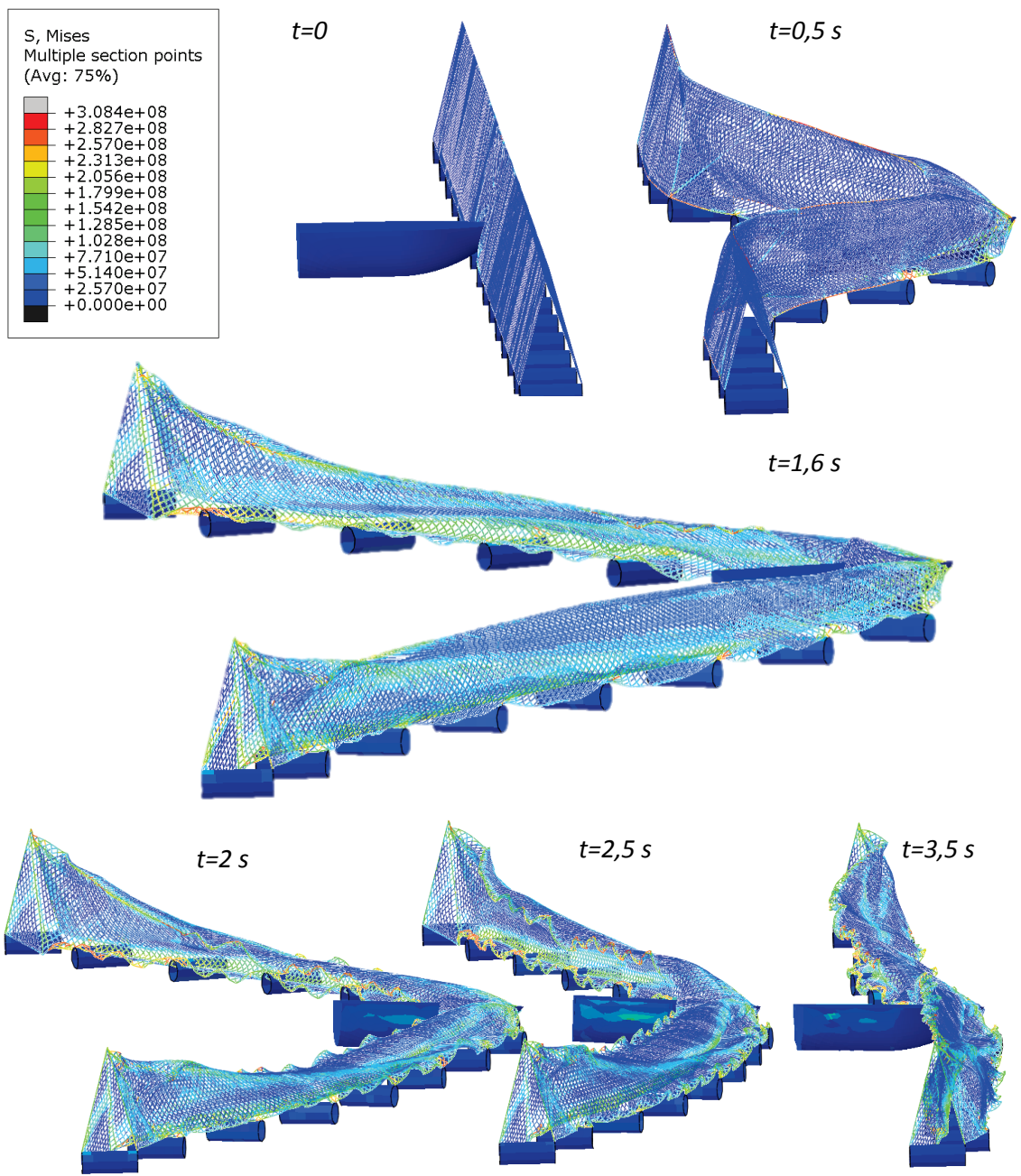

Rys. 6. Rozkład naprężeń w poszczególnych krokach czasowych dla zderzenia przy prędkości $\mathrm{V}=15,58 \mathrm{~m} / \mathrm{s}$

W pracy przedstawiono również rozproszenie prędkości oraz maksymalne przemieszczenia dziobnicy łodzi. Wyniki wskazują zgodność z eksperymentem, ponieważ siatka, nawet po uderzeniu łodzi z największą prędkością, wraca do położenia początkowego. Wskazują na to także naprężenia w barierze. Według wyników obliczeń maksymalne naprężenia wynoszą 308,4 MPa, co nieznacznie przekracza granicę plastyczności zamodelowanego materiału (rys. 7). Koncentracja 
maksymalnych naprężeń nie znajduje się $\mathrm{w}$ miejscu uderzenia, co wynika z uproszczeń i niedoskonałości modelu.

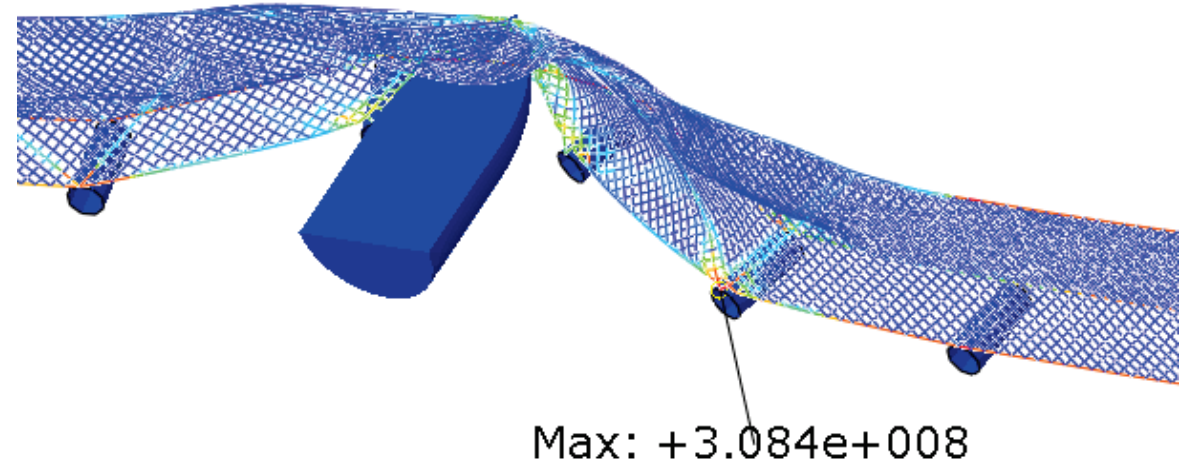

Rys. 7. Miejsce wystąpienia maksymalnych naprężeń

\section{Podsumowanie i wnioski}

W pracy przedstawiono pływające bariery FOXX jako środek ochrony przed zagrożeniami ze strony morza podczas postoju okrętu w porcie. Opisano testy przeprowadzone na Zalewie Zakrzówek w Krakowie oraz przytoczono wnioski z przeprowadzonych eksperymentów. Następnie stworzono model MES bariery oraz przeprowadzono symulację na podstawie eksperymentów. Wyniki zestawiono w formie wykresów oraz rysunków. Analizując wyniki wyciągnięto następujące wnioski:

- odpowiedni ciężar pływaków jest w stanie zasymulować opór wody $\mathrm{w}$ trakcie uderzenia. Na podstawie wielokrotnych symulacji dobrano mase pływaków w taki sposób, aby odwzorować zachowanie bariery. Masa pływaków w symulacji wynosiła $45 \mathrm{~kg}$;

- podczas zderzenia z maksymalną prędkością naprężenia w siatce osiagnęły granicę plastyczności zamodelowanego materiału jednak nie przekroczyły granicy wytrzymałości w miejscu uderzenia. Przekroczenie granicy plastyczności nastąpiło w węźle, w którym zamodelowano uproszczenie mocowania siatki do pływaków. W rzeczywistości miejsce to jest wzmocnione, co pozwala wykluczyć je, jako miejsce koncentracji naprężeń; 
- $\quad$ spadek prędkości w barierze zależy od prędkości zderzenia. Zderzenie $\mathrm{z}$ większą prędkością powoduje szybsze wyhamowanie łodzi. Maksymalne przemieszczenie łodzi wynosi $15 \mathrm{~m}$, po czym łódź zaczyna poruszać się w kierunku przeciwnym. Z wyników symulacji wynika, że bariera absorbuje średnio $25 \%$ energii kinetycznej zderzenia.

Podczas przeglądania wyników eksperymentu zwrócono uwagę na możliwe przejście dużej łodzi motorowej ponad barierą. Przygotowany model obliczeniowy pozwala na sprawdzenie możliwości przejścia nad barierą dowolnej jednostki, jednak ze względu na mnogość różnych konstrukcji nie zostały one przedstawione bezpośrednio w pracy.

$W$ prezentowanym artykule wykorzystano wyniki badań prowadzonych $w$ ramach projektu pk. ,AUSTENKA” kod M-1-1-1-021/20018 sfinansowanego przez MON.

\section{Literatura}

1. Abaqus 6.10, Theory Manual, Simulia, Dassault Systems, 2010.

2. Casualties: U.S. Navy and Marine Corps Personnel Killed and Wounded in Wars, Conflicts, Terrorist Acts, and Other Hostile Incidents. Naval History \& Heritage Command. Retrieved 15 July 2012.

3. https://www.naval-technology.com/contractors/fenders/geobrugg/

4. Johnson G.R., Cook W.H.: A Constitutive model and data for metal subjected to large strains, high strain rates and high temperatures, Proceedings of the 7 th International Symposium on Ballistics, 2009.

5. Krasauskas P., Kilikevičius S., Česnavičius R., Pačenga D.: Experimental analysis and numerical simulation of the stainless AISI 304 steel friction drilling proces. MECHANIKA, vol. 20 (6), 2014.

6. Kubiak K.: Broń nieśmiercionośna we współczesnych konfliktach zbrojnych. Zeszyty Naukowe AON, No. 1(70), Warszawa 2008.

7. Szubrycht T., Kowalski S.: Teoretyczne i praktyczne aspekty przeprowadzonych testów pływających siatkowych barier ochronnych. Logistyka, No. 5, 2011. 